\title{
IDENTIFICATION AND PHENOTYPIC CHARACTERISTICS OF LACTIC ACID BACTERIA ISOLATED FROM SOME TRADITIONAL CHEESES PRODUCED IN THE REPUBLIC OF MACEDONIA
}

\author{
Vesna Levkov $^{1}$, Sandra Mojsova $^{2}$, Rodne Nastova $^{1}$, Sonja Srbinovska $^{3}$, Natasha Gjorgovska ${ }^{1}$ \\ ${ }^{1}$ Institute of Animal Science, "Ss. Cyril and Methodius" University in Skopje, \\ Blvd. Ilinden 92a, Skopje, Republic of Macedonia \\ ${ }^{2}$ Faculty of Veterinary Medicine, "Ss. Cyril and Methodius" University in Skopje, \\ Lazar Pop-Trajkov 5-7, Skopje, Republic of Macedonia \\ ${ }^{3}$ Faculty of Agricultural Science and Food, "Ss. Cyril and Methodius" University in Skopje, \\ Blvd. Aleksandar Makedonski bb, Skopje, Republic of Macedonia \\ levkovv@yahoo.com
}

\begin{abstract}
The characteristics of lactic acid bacteria isolated from beaten cheese and white brined cheese produced from raw ewe's milk in traditional way were object of this study. From all the stages of beaten cheese manufacturing, 240 isolates were isolated. According to the phenotypic and biochemical characteristics, the prevailing species were Lactococcus lactis spp. lactis (35\%), Lactobacilus paracasei subsp. paracasei (22.5\%), Pediococcus sp. (16.7\%), L. plantarum $(15.8 \%)$, L. brevis $(9.17 \%)$ and Leuconostoc sp. (1\%). From white brined cheese 39 isolates were isolated belonging to the genera Lactobacillus (59\%), Enterococcus (23.1\%) and Leuconostoc (17.9\%), The prevalent species were identified as: E. durans, Leuconostoc mesenteroides subsp. Mesenteroides /dexstranicum, Lactobacillus plantarum and L. curvatus, mostly isolated in the early stages of cheese's ripening, and L. plantarum and L. paracase $i$ subsp. paracase $i$ isolated from ripened cheese samples. In both cheese types dominant species were mesophilic lactic acid bacteria characteristic for brined cheeses from north-eastern Mediterranean and Balkan countries.
\end{abstract}

Key words: lactic acid bacteria; phenotypic and biochemical characteristics; traditional cheese

\section{ИДЕНТИФИКАЦИЈА И ФЕНОТИПСКИ КАРАКТЕРИСТИКИ НА МЛЕЧНОКИСЕЛИНСКИ БАКТЕРИИ ИЗОЛИРАНИ ОД НЕКОИ ТРАДИЦИОНАЛНИ СИРЕЊА ПРОИЗВЕДЕНИ ВО РЕПУБЛИКА МАКЕДОНИЈА}

\begin{abstract}
Својствата на млечнокиселинските бактерии изолирани од традиционално биено сирење и бело саламурено сирење произведени од сурово овчо млеко се предмет на истражување во овој труд. Од сите производни фази на биеното сирење беа изолирани вкупно 240 изолати на млечнокиселински бактерии. Испитувањата на нивните фенотипски и биохемиски карактеристики укажуваат дека најзастапени видови биле: Lactococcus lactis spp. lactis (35\%), Lactobacilus paracasei ssp. paracasei (22.5\%), Pediococcus sp. (16.7\%), L. plantarum (15.8\%), L. brevis $(9.17 \%)$ и Leuconostoc sp. (1\%). Од белото саламурено сирење се изолирани 39 вида млечнокиселински бактерии кои припаѓаат на родовите Lactobacillus (59\%), Enterococcus (23.1\%) и Leuconostoc (17.9\%). Во раните стадиуми на зреење на сирењето најзастапени видови биле: E. durans, Leuconostoc mesenteroides ssp. mesenteroides / dexstranicum, Lactobacillus plantarum и L. curvatus, додека во зрелото сирење најзастапени биле $L$. plantarum и L. paracasei ssp. paracasei. Испитувањата покажале дека и во двата вида на сирење доминираат мезофилните млечнокиселински видови, и тоа оние својствени за саламурени сирења кои потекнуваат од североисточните медитерански и балкански земји.
\end{abstract}

Клучни зборови: млечнокиселински бактерии; фенотипски и биохемиски карактеристики; традиционално сирење

\section{INTRODUCTION}

Traditional cheeses made from raw milk are products characteristic for Mediterranean and Balkan countries. Their quality is influenced by the tra- dition of making in combination with the geographical region and its pedoclimatic characteristics, milk quality and the animal nourishment (Micari et al., 2007). Traditional cheeses are unique ecosystems 
containing different types of microorganisms with positive influence on cheese's ripening and its sensorial properties (Prodromou et al., 2001; Marino et al., 2003; Beresford and Williams, 2004).

The microorganisms can enter the cheese from raw milk, diary equipment and the environment during manufacturing and ripening (Manolopoulou et al., 2003; Beuvier and Buchin, 2004; Garabal, 2007).

The lactic acid bacteria are considered essential in cheese production because of their biochemical activity which, in cooperation with milk and rennet enzymes, creates the significant cheese characteristics (aroma, taste and texture). The lactic acid bacteria in raw milk cheeses are very diverse at generic level as well as in different species within the same genus (Beuvier and Buchin, 2004). To preserve the unique and typical characteristics of traditional cheeses and their microbial diversity it is necessary to study their microbiological characteristics (Hatzikamari et al., 1999; Xanthopoulos et al., 2000; Nikolaou et al., 2002; Manolopoulou et al., 2003; Psoni et al., 2003; Martinović et al., 2005; Terzić-Vidojević et al., 2007, 2009a).

White brined cheese, kashkaval and beaten cheese are the most popular kinds of traditional cheese produced in R. Macedonia. Their production is widespread in Macedonia especially in mountain and rural districts where they are important economic traits. The commercial starter cultures are not used and their production relies on the autochthonous lactic acid bacteria naturally present in raw milk. The traditional cheese properties can be changed and modified with the modernization and advancement of the cheese production technology, in order to obtain better-quality products that can affect microbial diversity. There are several studies regarding physico-chemical and microbiological characteristics of traditional white brined and beaten cheese (Levkov and Kakurinov, 2011; Mojsova et al., 2013; Levkov et al., 2014). In order to maintain the production of high-quality traditional cheeses it is necessary to study the microbial diversity especially the attendant lactic acid bacteria as essential for cheese production (Parente and Cogan, 2004; Özkalp et al., 2007).

The aim of this study was examination of wild lactic acid bacteria (LAB) isolated from traditional ewe's milk cheeses (white brined and beaten cheese) produced in different regions in R. Macedonia, their phenotypic, physiological and biochemical characteristics. Some technological characteristics of LAB isolated from white brined cheese are also presented for the purpose of obtaining information about their potential inclusion in the preparation of starter cultures in the future.

\section{MATERIAL AND METHODS}

Microbiological analyses were preformed on white brined cheese and beaten cheese produced from raw ewe's milk in traditional way.

The samples of beaten cheese were taken from all the stages of production (curd, draining, dry salting, brining) and come from two farmhouses (batch 1 and 2) situated in Mariovo region. They were taken within three different cheese production campaigns in each farmhouse. The white brined cheese samples were taken from four different farmhouses: $\mathrm{A}$ and $\mathrm{B}$ located in the regions of Debar and Gostivar in the western part of Macedonia, C and D located in the regions of Shtip and Kriva Palanka in the eastern part. The cheese samples were collected during the first week and after 90-100 days of ripening. All samples were collected aseptically and kept under refrigeration $\left(4-6^{\circ} \mathrm{C}\right)$ until the analysis.

\section{Microbiological analysis of beaten cheese}

For the isolation of lactic acid bacteria $10 \mathrm{~g}$ of each cheese sample were homogenized with $90 \mathrm{ml}$ of sterile $2 \%$ sodium citrate solution. Decimal dilution was made with sterile physiological solution and plated on M-17 and MRS agar. Gram-positive, catalase-negative cocci were grown on M-17 agar (Biolife, Milano, Italy) incubated at $30^{\circ} \mathrm{C}$ for $48-72$ h. Lactobacilli were grown on MRS agar (Biolife, Milano, Italy) at $30^{\circ} \mathrm{C}$ for 3-5 days under anaerobic conditions (GENbag anaerob, BioMérieux, France).

\section{Microbiological analysis of white brined cheese}

The samples taken from white brined cheese were prepared by dilution of $10 \mathrm{~g}$ of each sample with $90 \mathrm{~g}$ of Maximum Recovery Diluent (MRD) according to ISO 6887-1.

Mesophilic and thermophilic lactobacilli were grown on MRS agar (pH 5.5) with cycloheximide, incubated under anaerobic conditions (Gas-Pack anaerobic system, BioMérieux, France) at $30^{\circ} \mathrm{C}$ for $48-72 \mathrm{~h}$ and at $43^{\circ} \mathrm{C}$ for $72 \mathrm{~h}$. Leuconostoc species were isolated on MRS agar enriched with $100 \mu \mathrm{g} / \mathrm{ml}$ vancomycin hydrochloride hydrate (Sigma Aldrich) incubated at $30^{\circ} \mathrm{C}$ for $48 \mathrm{~h}$. Isolation of Enterococcus species were performed with selective Kanamycin aesculin azide agar (KAA, Oxoid, UK) incubated for $24 \mathrm{~h}$ at $37^{\circ} \mathrm{C}$. 
Lactic acid bacteria, from both cheese types, were obtained by random picking of colonies per cheese sample from M-17 and MRS agar plates. The isolates were purified by consecutive subculturing on M-17 and MRS agar. Purified isolates were stored in M-17 broth and MRS broth being subcultured at one- or two-month intervals. LAB isolates were determined to generic and species level by their morphological, physiological and biochemical characteristics according to the criteria of Bergey's manual of determinative bacteriology (Holt et al., 1994). The fermentative characteristics of representative samples were analyzed by using API 50 CHL system (BioMérieux). For determination of Enterococcus species VITEK2 Compact (BioMérieux, France) was used.

LAB isolates from white brined cheese were further examined for their proteolytic and lipolytic activities as well as their ability to metabolize citrate. Calcium caseinate agar (Fluka) and Tributyrin agar (Fluka) (at $35^{\circ} \mathrm{C}, 3-5$ days) were used to test their proteolytic and lipolytic activities. For examination of citrate utilization Simmons citrate Agar was used (incubation of 2-7 days at $35^{\circ} \mathrm{C}$ ).

\section{RESULTS AND DISCUSSION}

\section{Isolation and identification of isolates}

From traditional beaten cheese a total of 240 isolates of LAB were isolated from all the stages of manufacturing and ripening. The prevailing species in the cheese from both batches was Lactococcus lactis subsp. lactis (35\%) found in the early stages of cheese ripening. From all the isolates, $16.7 \%$ belong to the genus Pediococcus, and only $1 \%$ belong to the genus Leuconostoc which were isolated only from the batch 1 . Lactobacilli were mostly isolated at later stages of ripening. The most prevailing species in cheeses from both batches were Lactobacillus paracasei subsp. paracasei $(22.5 \%)$ and $L$. plantarum $(15.8 \%)$. The species L. brevis $(9.2 \%)$ was isolated during dry salting and brine ripening only from batch 1 .

L. lactis subsp. lactis was isolated from curd and cheese samples (after draining, dry ripening and dry salting) collected from both farmhouses until the process of cheese brining. Isolates determined as Pediococcus sp. were obtained from cheese samples collected during almost all the stages of production in both farms, and Leuconostoc sp. was obtained from curd samples collected from batch 1 . The lactobacilli were isolated from cheese samples during dry ripening, dry salting and brining. Lb. paracase $i$ subsp. paracase $i$ was also isolated from curd samples, and Lb. brevis was obtained only from cheese in batch 1 .

From white brined cheese a total of 39 isolates were taken after the first week of ripening and after 90-100 days of ripening. The prevailing species belong to the genus Lactobacillus (59\%), Enterococcus $(23.1 \%)$ and Leuconostoc (17.9\%). The analyses showed that there were some differences in the presence of lactic acid bacteria between the different cheese samples, as well as between same samples taken in different phases of ripening. In the cheese samples of the variant A after the first week of ripening the presence was found of $L b$. platarum, $L b$. curvatus and Lb. lidneri. On the other hand, in the ripened cheese (after 90-100 days of ripening) the presence was found of $L b$. plantarum, Lb. paracasei subsp. paracasei and Lb. brevis. In the variants $\mathrm{B}, \mathrm{C}$ and $\mathrm{D}$, in the ripened cheese samples, the presence was found of the same lactobacilli species, only with the exceptions that in the variant $\mathrm{C}$ instead of $L b$. brevis the presence of $L b$. fermentum was found, and in the variant $D$ was found only the presence of $L b$. plantarum. The species of lactobacilli isolated from fresh cheese samples B, C and D differ from those isolated from the variant $A$. In the variant B prevails $L b$. plantarum, in the variant $\mathrm{C}$ prevail $L b$. helveticus and $L b$. salivarius, and in the variant $\mathrm{D}$ are present $L b$. curvatus and $L b$. delbrueckii subsp. delbrueckii.

Members of the genus Leuconostoc, namely Leu. mesenteroides ssp mesenteroides/destranicum and Leu. lactis were isolated from fresh cheese samples from the variants $A$ and $D$, while from the variant B the species Leu. lactis was isolated, and from the variant $\mathrm{C}$ the species Leu. mesenteroides subsp. mesenteroides/dexstranicum. No presence of Leuconostoc species was found in the ripened cheese samples, with the exception of the variant $\mathrm{C}$ where from the species Leu. mesenteroides subsp. cremoris was isolated. The analyses of white brined cheese showed the presence of enterococci too. There were isolated: E. durans from the fresh cheese originating from the region of Debar (variant A); E. durans and E. faecium from both fresh and ripened cheese from Gostivar region (variant B); $E$. fecalis from the fresh cheese from the regions of Shtip and Kriva Palanka (variants C and D, respectively); and $E$. hirae and $E$. durans from the ripened cheese samples from Kriva Palanka (variant D). The presence of enterococci species in the beaten cheese wasn't object of investigation in this study, therefore no data on it are given here. 
The morphological characteristics of the colonies were observed and the prepared microscopic slides were revised. Isolates denoted as Gram-positive, catalase-negative, homofermentative cocci in pairs or short chain, which grew at $15^{\circ} \mathrm{C}$ but not at $45^{\circ} \mathrm{C}$, were considered as mesophilic lactococci. Their colonies were small, white, round or lenticular. Gram-positive, catalase-negative, homofermentative cocci grouped in tetrads, taken from small grayish or whitish colonies, were considered as Pediococcus. As presumptive Leuconostoc were considered heterofermentative, Gram-positive, catalase-negative isolates with small round or oval cocci in chains, with small and transparent colonies. Gram-positive, catalase-negative rods, homo- or heterofermentative, individually or in pairs, which grew at $15^{\circ} \mathrm{C}, 30^{\circ} \mathrm{C}$ and $45^{\circ} \mathrm{C}$, were considered being Lactobacillus. Their colonies were small, white, round or lenticular. The biochemical and physiological characteristics of the strains isolated from beaten cheese and white brined cheese are shown in Table 1 and Table 2 .

Table 1

Morphological, cultural and physiological characteristics of lactic acid bacteria isolated from beaten cheese

\begin{tabular}{|c|c|c|c|c|c|c|}
\hline Tests & $\begin{array}{l}\text { L. lactis ssp. } \\
\text { lactis }\end{array}$ & $\begin{array}{l}\text { Lactobacillus } \\
\text { plantarum }\end{array}$ & $\begin{array}{l}\text { L. pracasei } \mathrm{ssp} . \\
\text { paracasei }\end{array}$ & L.brevis & Pediococcus sp. & Leuconstoc sp. \\
\hline Growth at $15^{\circ} \mathrm{C}$ & + & + & + & + & + & + \\
\hline Growth at $30^{\circ} \mathrm{C}$ & + & + & + & + & + & + \\
\hline Growth at $45^{\circ} \mathrm{C}$ & - & - & - & - & + & - \\
\hline Growth in $4 \% \mathrm{NaCl}$ & + & + & + & + & + & $+/-$ \\
\hline Growth in $6 \% \mathrm{NaCl}$ & + & + & + & + & + & - \\
\hline \multicolumn{7}{|c|}{ Acid production from/hydrolisis of } \\
\hline L-arabinose & - & - & - & + & - & - \\
\hline D-ribose & + & + & + & + & + & + \\
\hline D-xylose & + & - & - & + & - & + \\
\hline Galactose & + & + & + & + & + & + \\
\hline Glucose & + & + & + & + & + & + \\
\hline Fructose & + & + & + & + & + & + \\
\hline Mannose & + & + & + & + & + & + \\
\hline Mannitol & + & + & + & - & - & + \\
\hline Sorbitol & - & - & + & - & - & \\
\hline Methyl- $\alpha \mathrm{D}-$ Glucopyranoside & - & - & - & - & - & + \\
\hline $\mathrm{N}$-acetylglucosamine & + & + & + & + & + & + \\
\hline Amygdalin & + & + & + & + & + & + \\
\hline Arbutin & + & + & + & + & + & + \\
\hline Aesculine & + & + & + & + & + & $\mathrm{v}$ \\
\hline Salicin & + & + & + & + & + & + \\
\hline Cellobiose & + & + & + & + & + & + \\
\hline Maltose & + & + & + & + & + & + \\
\hline Lactose & + & + & + & + & + & + \\
\hline Melibiose & - & + & - & + & - & - \\
\hline Saccharose & + & + & - & - & - & + \\
\hline Trehalose & + & + & + & + & + & + \\
\hline Inulin & - & - & - & - & - & - \\
\hline Melezitose & - & + & - & - & - & - \\
\hline Raffinose & - & + & - & - & - & - \\
\hline Gentiobiose & + & + & + & + & + & $\mathrm{v}$ \\
\hline Turanose & - & - & + & - & - & + \\
\hline Tagatose & - & - & - & + & + & - \\
\hline Potassium gluconate & - & - & - & - & - & $\mathrm{v}$ \\
\hline
\end{tabular}


Table 2

Morphological, cultural and physiological characteristics of some lactic acid bacteria isolated from white brined cheese

\begin{tabular}{|c|c|c|c|c|c|c|c|c|c|c|c|}
\hline Tests & 1 & 2 & 3 & 4 & 5 & 6 & \multicolumn{2}{|c|}{7} & 8 & 9 & 10 \\
\hline Growth at $15^{\circ} \mathrm{C}$ & + & + & - & + & - & - & + & + & + & + & + \\
\hline Growth at $45^{\circ} \mathrm{C}$ & - & - & + & - & + & + & - & - & - & - & - \\
\hline Growth in $4 \% \mathrm{NaCl}$ & + & + & + & + & + & + & $+/-$ & - & - & - & - \\
\hline Growth in $6 \% \mathrm{NaCl}$ & + & + & - & + & + & + & - & - & - & - & - \\
\hline \multicolumn{12}{|c|}{ Acid production from/hydrolisis of } \\
\hline $\mathrm{L}$-arabinose & + & + & + & - & - & - & - & + & - & + & - \\
\hline D-ribose & + & + & + & + & - & - & - & - & - & - & - \\
\hline D-xylose & + & - & + & - & - & - & - & + & - & + & - \\
\hline Galactose & + & + & + & + & + & + & + & + & + & + & - \\
\hline Glucose & + & + & + & + & + & + & + & + & + & + & + \\
\hline Fructose & + & + & - & + & + & + & + & + & + & + & - \\
\hline Mannose & - & + & - & + & + & + & + & + & + & + & - \\
\hline Mannitol & - & + & - & + & - & - & - & $\mathrm{v}$ & - & + & - \\
\hline Sorbitol & - & + & - & - & - & - & - & - & - & - & - \\
\hline Methyl- $\alpha$ D-Mannopyranoside & - & + & - & - & - & - & - & - & - & - & - \\
\hline Methyl- $\alpha$ D-Glucopyranoside & - & - & - & - & - & $\mathrm{v}$ & + & + & + & + & - \\
\hline $\mathrm{N}$-acetyl-glucosamine & + & + & - & + & + & $\mathrm{v}$ & + & + & + & + & + \\
\hline Amygdalin & + & + & - & + & - & - & - & - & - & - & - \\
\hline Arbutin & + & + & - & + & - & - & - & - & - & - & - \\
\hline Aesculin & + & + & - & + & - & + & - & + & - & + & - \\
\hline Salicin & + & + & - & + & - & - & - & $\mathrm{v}$ & - & $\mathrm{v}$ & - \\
\hline Cellobiose & + & + & - & + & - & - & - & - & - & - & - \\
\hline Maltose & + & + & + & + & - & + & + & + & $\mathrm{v}$ & + & - \\
\hline Lactose & + & + & + & + & - & + & + & + & + & + & + \\
\hline Melibiose & + & + & + & - & - & $\mathrm{v}$ & + & + & & + & - \\
\hline Saccharose & - & + & - & + & - & + & + & + & + & + & - \\
\hline Trehalose & + & + & - & + & - & $\mathrm{v}$ & + & + & + & + & - \\
\hline Melezitose & - & + & - & + & - & - & - & - & - & - & - \\
\hline Raffinose & - & + & + & - & - & $\mathrm{v}$ & - & + & - & - & - \\
\hline Xylitol & - & - & - & - & - & - & - & - & - & - & - \\
\hline Gentiobiose & + & + & - & + & - & - & - & - & + & - & - \\
\hline Turanose & - & + & - & - & - & - & + & + & + & - & - \\
\hline Tagatose & - & - & - & - & - & - & - & - & - & - & - \\
\hline D-arabitol & - & - & - & $\mathrm{v}$ & - & - & - & - & - & - & - \\
\hline Potassium gluconate & + & + & - & - & - & - & - & - & - & - & - \\
\hline Potassium 5-etogluconate & $\mathrm{v}$ & - & - & - & - & - & - & - & - & - & - \\
\hline
\end{tabular}

1 - Lb. brevis; 2 - Lb. plantarum; 3 - Lb. fermentum; 4 - Lb. paracasei subsp. paracasei; 5 - Lb. helveticus; 6 - Lb. acidophilus; 7 - Leu. mesenteroides ssp. mesenteroides/dexstranicum; 8 - Leu. lactis; 9 - Leu. mesenteroides ssp. mesenteroides; 10 - Leu. mesenteroides subsp. cremoris

Very remarkable is the difference in the species composition of the lactic acid bacteria isolated from the both types of cheese, whereat in the beaten cheese prevail the mesophilic LAB while in the white brined cheese is noticeable also the presence of thermophilic LAB such as Lb. helveticus, Lb. delbrueckii subsp. delbrueckii, Lb. fermentum, Lb. salivarius. The diversity and the difference in the LAB 
species composition is influenced by the animals' race, the geographic characteristics of the locations where the cheese has been produced, i.e. the climatic conditions, the composition of the soil, the way of the animals' nutrition, the vegetation in the pastures, as well as the conditions of cheese's ripening and storage. There is an additional influence also of the microflora present on the tools for production, and of course of the technology of production of the examined sorts of cheese (Centeno et al., 1996; Terzić-Vidojević et al., 2007).

From the tables it is obvious that the same LAB species isolated from different cheese samples show some differences regarding their ability for metabolizing certain chemical compounds. In example, the species $L b$. plantarum isolated from the beaten cheese, for the difference from the same species isolated from the white brined cheese, doesn't ferment arabinose, sorbitol, turanose and Methyl$\alpha \mathrm{D}$-Mannopyranoside. In comparison with the results obtained by Tserovska et al. (2000) and Boukhemis et al. (2009) similar fermentative properties of this species are evident, while in comparison with the results obtained by Badis et al. (2004) and Terzić-Vidojević et al. (2009b) some differences are noticeable regarding this species' ability for fermenting the xylose, arabinose, salicin and sorbitol. The biochemical properties of $L b$. brevis isolated from the beaten cheese and white brined cheese are quite different from those found in the investigations made by Badis et al. (2004) regarding the ability for fermenting the mannose, saccharose, raffinose and sorbitol. In comparison with the results obtained by Terzić-Vidojević et al. (2009b), there is a difference in the ability for hydrolyzing the aesculin and fermenting the manose, salicin, cellobiose and trehalose, while in comparison with the results from the investigations made by Boukhemis et al. (2000) there is a difference regarding the ability for fermenting the xylose, cellobiose, raffinose, saccharose and sorbitol (Table 1 and Table 2).

Lb. paracasei subsp. paracasei is a species prevailing in the both types of traditional cheese. Its fermentative properties are similar to those of the species isolated from milk products from Azerbaidzhan (Terzić-Vidojević et al., 2009b), but differ from the results obtained by Badis et al. (2004) regarding its ability for fermenting the galactose, melibiose, raffinose, xylose as well as hydrolyzing the aesculin. Lb. fermentum isolated from the white brined cheese shows certain differences regarding its fermentative properties compared to the results obtained by Boukhemis et al. (2009), precisely regarding the fermentation of arabinose, cellobiose, fructose, manose, melezitose, saccharose and $\mathrm{xy}$ lose (Table 2). Lb. helveticus isolated from the white brined cheese doesn't ferment the maltose, lactose and trehalose, which differs from the results obtained by Tserovska et al. (2000), showing fermentative properties similar to those found in the investigations made by Badis et al. (2004) and Boukhemis et al. (2009). On the other hand, Lb. acidophilus shows similar properties with those of the species investigated by Boukhemis et al. (2000), showing difference only regarding the ability for fermenting the cellobiose and salicin (Table 2).

Concerning the fermentative properties of $L$. lactis subsp. lactis isolated from the beaten cheese, certain differences are noticeable from the results obtained by Badis et al. (2004) regarding the hydrolyzis of aesculin and fermentation of melibiose, raffinose and saccharose (Table 1). It is also noticeable that this species shows ability of growth in the conditions of higher concentration of salt $(6.5 \%)$ which, according to Corroler et al. (1998), is not surprising since natural lactococci can survive in adverse conditions.

The fermentative properties of the members of the genus Leuconostoc isolated from the beaten cheese and the white brined cheese are given in Table 1 and Table 2, respectively. From the white brined cheese 2 species of Leu. mesenteroides ssp. mesenteroides/dexstranicum were extracted that shows certain differences in fermentative properties (Table 2). The species Leu. lactis isolated from white brined cheese features fermentative properties similar to those of the species isolated from raw goat milk (Badis et al., 2004), except regarding the ability for fermenting the manose.

The isolate identified as Pediococcus sp. extracted from the beaten cheese shows very similar biochemical properties compared with the pediococci examined by Tserovska et al. (2000) and the criterions on fermentation laid by Lahtinen et al. (2012). From the aforementioned properties of the isolated lactic acid bacteria species it can be see that their phenotypic properties are in accordance with the data in the literature (Tserovska et al, 2000; Badis et al., 2004; Boukhemis et al., 2009), but there is a variation in their fermentative profile. This variation is noticeable between the species isolated from the traditional cheeses examined in this study, but also from the species examined by the authors mentioned above. According to Boukhemis et al. (2009), the fermentative profile very often depends on the particular species or strain of LAB and is related with the plasmids within LAB's cells or their 
genes responsible for assimilation and transportation of carbohydrates.

The lactic acid bacteria species' presence is in line with the finds of many authors who have examined various types of traditional cheeses (Martinović et al., 2005; Pešić-Mikulec \& Jovanović, 2005; Nikolić et al., 2008; Kamber \& Çelik, 2007; Kirdar \& Kursun, 2011; Centi et al., 2017). According to them, in the traditional cheeses a wider presence is enjoyed by the following species: Lactococcus lactis subsp. lactis, Lactobacillus paracasei subsp. paracasei, L. plantarum, L. paraplantarum, L. brevis, L. fermentum, Leuconostoc lactis, E. faecalis, E. faecium, and members of the genus Pediococcus. The importance of the isolated species is also pointed out by Bintsis \& Papademas (2002), Beuvier and Buchin (2004), according to whom the isolated species are typical for the traditional cheeses that ripen in brine, and are produced in the northeast Mediterranean countries and in the Balkan countries.

\section{Technological characteristics of isolates}

Additional examinations were done also of some technological properties of LAB isolated from the white brined cheese. The results show that the species Lb. plantarum, Lb. paracasei subsp. Paracasei and $L b$. brevis isolated from both fresh and ripened white brined cheese are proteolytically active whereas no lipolytic or citrate-positive activity was found.

The examinations of the members of Leuconostoc species showed that they don't have any proteolytic or citrate-positive activity. For the difference, all the isolates of enterococci were proteolytically active, while E. faecium showed both lipolytic and citrate-positive activity. These finds indicate that the aforementioned species of lactobacilli and enterococci most probably have some influence on the taste and the aroma of the white brined cheese and that they are very well adapted to the ecological conditions present during the process of cheese's ripening (Nikolić et al., 2008). The presence of enteroccoci, in particular of the species E. faecium and $E$. durans in the traditional cheeses was registered also by other authors (Psoni et al., 2006; TerzićVidojević et al., 2009c; Centi et al., 2017), in whose investigations the isolates had mostly shown proteolytical activity. On the other hand, the investigations made by Morales et al. (2011) show that the isolated strains of E. faecium have both proteolytical and lipolytical activity. The proteolytical activity of the lactobacilli as well as of the members of
Leuconstoc sp. were object of research of other authors as well (Xanthopoulos et al., 2000; Özkalp et al., 2007; Nikolić et al., 2008; Terzić-Vidojević et al., 2009b; Franciosi et al., 2009), according to whom the isolated LAB species and strains had shown different ability for decomposition of the proteins in the cheese.

\section{CONCLUSION}

From the investigations made of the lactic acid bacteria isolated from the traditional cheeses it is evident that in the beaten cheese prevail mesophilic lactic acid bacteria, while in the white brined cheese was also found the presence of thermophilic bacteria. From the both types of cheese were isolated and identified the same LAB species which nevertheless differ one from another regarding their biochemical characteristics. It is necessary these investigations to be supplemented with genotypic identifications of LAB because of the discrepancy between the phenotypical and the genotypical way of identification. In terms of the technological characteristics of the isolated LAB, only certain types of lactobacilli and enterococci show proteolytic activity. The results presented in this paper are of importance since they give initial information about the characteristics of the lactic acid bacteria which might be of use in designing the starter cultures. To this purpose, additional and more comprehensive investigations of the technological properties of the isolated LAB are necessary.

\section{REFERENCES}

[1] Badis A., Guetarni D., Moussa-Boudjemâa B., Henni D. E., Tornadijo M. E., Kihal M.: Identification of cultivable lactic acid bacteria isolated from Algerian raw goat's milk and evaluation of their technological properties. Food Microbiology, 21: 343-349 (2004).

[2] Beuvier E., Buchin S., 2004. The microbiology of cheese ripening. In: Fox P.F., McSweeney P.H., Cogan T.M., Guinee T. P. (Eds): Cheese, Chemistry, Physics and Microbiology. Vol. 1, General Aspects, Academic Press., 2004, pp. 287-317.

https://doi.org/10.1016/S1874-558X(04)80071-X

[3] Beuvier E., Buchin S., 2004. Raw milk cheeses. In: Fox P.F., McSweeney P.H., Cogan T.M., Guinee T. P. (Eds): Cheese, Chemistry, Physics and Microbiology. Vol. 1, General Aspects, Academic Press. pp. 319-345, 2004. http://dx.doi.org/10.1016/S1874-558X(04)80072-1.

[4] Bintsis T., Papademas P.: Microbiological quality of white-brined cheese: a review. International Journal of Dairy Technology, 55 (3), 113-120 (2002). 
[5] Boukhemis M., Djeghri-Hocine B., Tahar A., Amrane A.: Phenotypic characterization of Lactobacillus starins isolated from different biotopes. African Journal of Biotechnology, 8 (19): 5011-5020 (2009).

[6] Centeno J. A., Menendez S., Rodriguez-Otero J. L.: Main microbial flora present as natural starters in Cebreiro raw cow's milk cheese (Northwest Spain). International Journal of Food Microbiology, 33, 307-313 (1996).

[7] Centi V., Matteucci F., Lepidi A., Del Gallo M., Ercole C.: Microbial and biochemical aspects of inland Pecorino Abruzzese cheese. Heliyon 3, 1-26 (2017).

[8] Corroler, D., Mangin, I., Desmasures, N., Gueguen, M.: An ecological study of lactococci isolated from raw milk in the Camembert cheese Registered Designation of Origin area. Applied and Environmental Microbiology 64, 47294735 (1998).

[9] Franciosi E., Settanni L., Cavazza A., Poznanski E.: Biodiversity and technological potential of wild lactic acid bacteria from raw cow's milk. International Dairy Journal, 19: 3-11 (2009).

[10] Garabal J. I.: Biodiversity and survival of autochthonnous fermented products. International Microbiology, 10, 1-3 (2007).

[11] Hatzikamari M., Litopoulou-Tzanetaki E., Tzanetakis N.: Microbiological characteristics of Anevato: a traditional Greek cheese. Journal of Applied Microbiology, 87, 595601 (1999).

[12] Holt, J. G., Krieg, N. R., Sneath, N. R., Staley, J. T., Williams, S. T.: Gram-positive cocci, In: Bergey's Manual of Determinative Bacteriology, $9_{t h}$ ed. Hensyl, W. R. (ed): London, Williams \& Wilkins, 1994, pp. 527-558.

[13] ISO 6887-1.

[14] Kamber U., Çelik T. H.: Some microbiological and chemical characteristics of Gorcola cheese. YYÜ Vet Fak Derg, 18 (1), 87-92 (2007).

[15] Kirdar S. S., Kursun O.: Microflora and pathogen bacteria in traditional Anatolian Canak (Pan) cheese. Journal of Animal and Veterinary Advances, 10 (19), 2511-2515 (2011).

[16] Huys G., Leisner J., Björkroth J.: The lesser LAB Gods: Pediococcus, Leuconostoc, Weissella, Carnobacterium and Affiliated Genera. In: (Eds.) Lahtinen S., Ouwehand A.C., Salminen S., Von Wright A.: Lactic Acid Bacteria Microbiological and Functional Aspects. Vol 1. CRC PressTaylor and Francis Group, 2012, pp. 93-121,.

[17] Levkov, V., Kakurinov, V.: Microbiological properties of artisanal cheese (Bieno sirenje). Journal of Hygienic Engineering and Design, 1, 325-329 (2011).

[18] Levkov V., Srbinovska S., Gjorgovska N.: Microbiological and chemical characteristics of traditional ewe's milk cheese from Mariovo region. Mljekarstvo, 64 (3), 195-206 (2014).

[19] Manolopoulou E., Sarantinopoulos P., Zoidou E., Aktypis A., Moschopoulou E., Kandarakis I. G., Anifantakis E. M.: Evolution of microbial populations during traditional Feta cheese manufacture and ripening. International Journal of Food Microbiology, 82, 153-161 (2003).

[20] Marino M., Maifreni M., Rondinini G.: Microbiological characterization of artisanal Montasio cheese: analysis of its indigenous lactic acid bacteria. FEMS Microbiology Letters, 229. 133-140 (2003).
[21] Martinović A., Radulović Z., Wind A., Janzen T., Obradović D.: Isolation and characterization of bacterial flora from farmhouse fermented milk products of Serbia and Montenegro. Acta veterinaria (Beograd), 55 (4), 307-318 (2005).

[22] Micari P., Sarullo V., Sidari R., Caridi A.: Physico-chemical and hygienic characteristics of the Calabrian raw milk cheese, Caprino d'Aspromonte. Turkish Journal of Veterinary and Animal Science, 31 (1), 55-60 (2007).

[23] Mojsova S., Janakuloski D., Sekulovski P., Angelovski Lj., Ratkova M., Prodanov M.: Microbiological properties and chemical composition of Macedonian traditional white brined cheese. Macedonian Veterinary Review, 36 (1), 13 18 (2013).

[24] Morales F., Morales J. I., Hernandez C. H., HernandezSanchez H.: Isolation and partial characterization of halotolerant lactic acid bacteria from two Mexican cheeses. Applied Biochemistry and Biotechnology, 164, 889-905 (2011).

[25] Nikolaou E., Tzanetakis N., Litopoulou-Tzanetaki E., Robinson R. K.: Changes in the microbiological and chemical characteristics of an artisanal, low-fat cheese made from raw ovine milk during ripening. International Journal of Dairy Technology, 55 (1), 12-17 (2002).

[26] Nikolić M., Terzić-Vidojević A., Jovšić B., Begović J., Golić N., Topisirović Lj.: Characterization of lactic acid bacteria isolated from Bukuljac, a homemade goat's milk cheese. Intenational Journal of Food Microbiology, 122. 162-170 (2008).

[27] Özkalp B., Özden B., Tuncer Y., Şanlibaba P., Ançelik M.: Technological characterization of wild-type Lactococcus lactis starins isolated from raw milk and traditional fermented milk products in Turkey. Lait, 87, 521-534 (2007).

[28] Parente E., Cogan T. M.: Starter culture: General aspects. In: (Eds) Fox P. F., McSweeney P. H., Cogan T. M., Guinee T. P.: Cheese, Chemistry, Physics and Microbiology. Vol. 1, General Aspects, Academic Press. 2004, pp. 123-148.

[29] Pešić-Mikulec D., Jovanović L.: Microbiological study of fresh white cheese (A Serbian craft variety). Applied Ecology and Environmental Research, 4 (1), 129-134 (2005).

[30] Prodromou K., Thasitou P., Haritonidou E., Tzanetakis N., Litopoulou-Tzanetaki E.: Microbiology of Orinotyri, a ewe's milk cheese from Greek mountains. Food Microbiology, 18, 319-328 (2001).

[31] Psoni L., Tzanetakis N., Litopoulou-Tzanetaki E.: Microbiological characteristics of Batzos, a traditional Greek cheese from raw goat's milk. Food Microbiology, 20, 575582 (2003).

[32] Terzić-Vidojević A., Vukaśinović M., Veljović K., Ostojić M., Topisirović Lj.: Characterization of microflora in homemade semi-hard white Zlatar Cheese. International Journal of Food Microbiology, 114, 36-42 (2007).

[33] Terzić-Vidojević A., Nikolić M., Veljović K., Tolinački M., Busarčević M., Topisirović Lj.: Analysis of the lactic acid bacteria microflora in traditional caucasus cow's milk cheeses. Archiva of Biological Science Belgrade, 61 (3), 395-406 (2009a).

[34] Terzić-Vidojević A., Veljović K., Tolinački M., Lozo J., Begović J., Gulahmadov S., Kuliev A. A., Delgalarrondo M., Chobert J. M., Haertlé T., Topisirović Lj.: Phenotypic 
and genotypic characterization of lactic acid bacteria isolated from Azerbaijani traditional dairy products. African Journal of Biotechnology, 8 (11), 2576-2588 (2009b).

[35] Tserovska L., Stefanova S., Yordanova T.: Identification of lactic acid bacteria isolated from Katyk, goat's milk and cheese. Journal of Culture Collection, 48-52 (20002002).
[36] Xanthopoulos V., Hatzikamari M., Adamidis T., Tsakalidou E., Tzanetakis N., Litopoulou-Tzanetaki E.: Heterogeneity of Lactobacillus plantarum isolates from Feta cheese throughout ripening. Journal of Applied Microbiology, 88, 1056-1064 (2000). 
